\title{
Open Skies or Closed Airports? Europe's Dilemma for a Sustainable Aviation Strategy
}

\author{
Padraic Regan ${ }^{1}$ \\ ${ }^{1}$ School of Business, Trinity College Dublin, Ireland \\ Correspondence: Padraic Regan, School of Business, Trinity College Dublin, Ireland. Tel: 353-1-896-2688. \\ E-mail: reganpa@tcd.ie
}

Received: April 16, 2014

Accepted: May 4, 2014 Online Published: May 27, 2014

doi:10.5539/jms.v4n2p106

URL: http://dx.doi.org/10.5539/jms.v4n2p106

\begin{abstract}
On the $20^{\text {th }}$ Anniversary of Europe's 'Third Package' of air transport liberalisation measures, it seems appropriate to examine its effectiveness as a strategy in terms of sustainability. The relaxation and elimination of restrictions greatly opened up air travel both within Europe and between Europe and the world. However, it also had dramatic consequences for $\mathrm{CO} 2$ emissions and airport congestion. In essence, the question being posed is: how does Europe propose to reconcile the conflicting objectives of air transport liberalisation and environmental sustainability? This paper assesses the current strategy in light of recent information on the capacity status of Europe's top airports. Based on increasing $\mathrm{CO} 2$ emissions, the absence of a global agreement on how to tackle same and increasingly congested hub airports, resulting in longer flight delays, the evidence would suggest that the challenge is substantial and some type of re-regulation may form part of the solution.
\end{abstract}

Keywords: air transport, sustainability, liberalisation, deregulation, airports

\section{Introduction}

"Even with slower growth, emissions from aviation are likely to increase" (Eurocontrol, 2013: 4)

Unlike the approach taken with the Airline Deregulation Act of 1978 in the United States, liberalization of air transport in Europe took the form of a phased replacement of bilateral air services agreements between pairs of countries with a single European market. Although there were three 'Packages' of measures, in effect there were four phases, viz. (i) the First Package in December 1987 focussed on reducing fare restrictions and allowing more cooperation between airlines; (ii) the Second Package in 1990 further curbed fare and capacity constraints as well as permitting $3^{\text {rd }}$ and $4^{\text {th }}$ freedom rights within Europe for European Union (EU) carriers (and freed-up the use of $5^{\text {th }}$ freedom rights); (iii) the Third Package came into force on $1^{\text {st }}$ January 1993 introduced common licensing of airlines and removed virtually all fare restrictions, and (iv) on $1^{\text {st }}$ April 1997 (as a final part of the Third Package), all community licensed carriers were granted cabotage rights (Reynolds-Feighan \& Button, 1999). Cabotage rights permit EU airlines to operate flights within the European Union whose origin and destination are not in their home country.

The completion of the European Union's Single Market in air transport heralded the transformation of an industry characterised by protection and fragmentation to one characterised by competition and commercialism. Scheduled airline numbers in Europe increased from 77 in 1992 to 139 in 2000, many of them low fare airlines (Budd et al, 2014) whose explosive growth can be indicated by comparing the number of seats offered by these carriers over a seven-day period in July 2000 of 750,000 with the number for the same week in 2004, 7.5 million (ELFAA, 2004). Between 1992 and 2000, the number of scheduled domestic flights increased by $49 \%$ whilst international flights within the EU witnessed a growth of $88 \%$ (ICAO, 2003).

Although different in many ways, the deregulation strategies of the US and Europe shared a common interest "to introduce, implement and protect the competitive marketplace" (Goetz \& Graham, 2004: 270). It wasn't long however before the economic benefits of liberalisation in Europe were taking their toll on other parts of the system with Upham and colleagues (2003) questioning the environmental sustainability of the air transport industry and the International Civil Aviation Organisation (ICAO) reporting that "...well over half of the 20 densest routes within the EU have a seriously constrained airport at one or both ends" (2003: 5). Reconciling this 
'clash' of liberalisation, globalisation and sustainability led Goetz and Graham to conclude that "infinite mobility is not attainable" (2004: 266).

\section{Liberalisation and Sustainability}

Defined by Black as "satisfying current transport and mobility needs without compromising the ability of future generations to meet these needs" (1996: 151), sustainable transport can be said to have three conditions, viz. (i) renewable resources are not consumed at a rate that exceeds their generation; (ii) non-renewable resources are not consumed at a rate that exceeds the development of sustainable renewable substitutes; and (iii) the environment's assimiliative capacity is not exceeded by pollution emissions (Akerman, 2005; Greene \& Wegener, 1997). In the case of aviation, these conditions are at risk from noise pollution (Suau-Sanchez et al, 2011), atmospheric pollution (principally CO2), ground pollution at airports, and aviation fuel consumption exceeding the development of substitutes (Goetz \& Graham, 2004).

In a bid to tackle climate change, the European Union (EU) launched its Emissions Trading System (ETS) in 2005 and implemented it over three phases, viz. (i) Phase 1: 2005-2007; covering only CO2 emissions from power generators and energy-intensive sectors; (ii) Phase 2: 2008-2012; coinciding with Kyoto Protocol commitments and including aviation in the system (to take effect from $1^{\text {st }}$ January 2012); and Phase 3: 2013-2020; covering more than 11,000 industrial plants in 31 countries (some $45 \%$ of the EU's greenhouse gas emissions) and involving a single EU-wide cap on emissions and auctioning of allowances. Under this 'cap-and-trade' system, a permit for every metric ton of $\mathrm{CO} 2$ emitted is required or a penalty of 100 euro per ton is levied. (The so-called 'Trading Period' has been termed Phase 4 covering 2021-2028).

As aviation emissions account for approximately $5 \%$ of all global warming and air transport $\mathrm{CO} 2$ is projected to increase four-fold by 2050 (IEA, 2009), the application of the ETS to aviation is particularly important (flying London/New York return is equivalent in terms of emissions as heating an EU house for twelve months). Some $85 \%$ of emission allowances will be allocated for free to the aviation sector (covering over 900 aircraft operators) over the course of Phase 3 whilst the remaining $15 \%$ will be auctioned.

Where the difficulties have arisen in respect of the system, however, is in its application to international flights into and out of non-ETS countries. Objections arose from many countries, including the U.S., China and Russia, stating that the United Nation's ICAO was the appropriate forum for setting and implementing a global aviation on pollution cubs. In agreeing to defer the application of the trading system to flights into and out of Europe (the so-called 'stop-the-clock' proposal) in 2012 for a twelve month period in order to allow time for ICAO's $38^{\text {th }}$ Assembly (the ICAO Council includes 36 countries) in Autumn 2013 to develop a market-based global policy, the EU set out the following conditions for such a policy, viz. (i) the emission reduction targets must be greater than or equal to those of the ETS; (ii) it must not discriminate between airlines; and (iii) targets and measures for ICAO members must be included. Although alternatives to this trading system exist, e.g. a fuel tax, the EU believes that "ETS provides the same environmental benefit at a lower cost to society-or a higher environmental benefit for the same cost" (European Commission, July 2013). A month later, support for the trading system emerged from a report conducted by David Lee and colleagues which concluded that the ETS provided the quickest and most effective method of curbing the impact of aviation on the climate (Lee et al., 2013). Given that ICAO has been deliberating over a global aviation emissions policy for some 17 years however, the prospects for an acceptable solution being agreed at this Assembly were never particularly encouraging. The $38^{\text {th }}$ ICAO Assembly ended with a decision by States to report back to the $39^{\text {th }}$ Assembly in 2016 on how a market-based measure could be implemented globally from 2020 (ICAO, 2013).

In the meanwhile, congestion levels and their associated delays at Europe's hub airports continue to grow. Eurocontrol's 'Challenges of Growth 2013' Report published in July of 2013 developed four scenarios for projecting air transport demand up to 2035 and 2050. The scenarios were generated from different combinations of the key predictors of air travel including economic growth, elasticities, environmental regulation and network structure with the most likely scenario (Scenario C: Regulated Growth) forecasting 14.4 million flights in Europe by 2035 , an increase of 1.5 times over 2012 and 18.6 million by 2050, twice the level of 2012. Some 1.9 million flights or $12 \%$ of demand (equivalent to nine runways) involving 237 million passengers will not be satisfied by 2035. At least 19 European airports will be operating at full capacity in 2030 with $50 \%$ of their flights affected by delays (the respective figures for 2007 were 5 and 17\%). European airports that in 2008 planned an almost $40 \%$ increase in capacity by 2030 were cutting back to $17 \%$ by 2035 as a result of economic recession, high capital costs, lack of political will and limited confidence in planning processes (ACI, 2013).

The countries that will be most severely hit by congestion include Turkey, the UK, the Netherlands, Bulgaria, Hungary, Germany, Poland and Italy but the repercussions will be felt throughout Europe. Average delay time 
per flight is set to increase from one minute to five/six minutes (Eurocontrol, 2013). By 2035, the economic impact of this congestion is estimated to cost airlines and airports Eur40 billion per annum and represent a loss to Europe of Eur230 billion in GDP (ACI, 2013).

Numerous methods of creating a more competitive air transport market in Europe have been attempted including regulations relating to slot allocation (Madas \& Zografos, 2008), airport charges (Bilotkach et al., 2011; IATA, 2011), ground handling (Aisling-Feighan \& Button, 1999), and computerised reservations systems (Barrett, 1992). Moreover, Eurocontrol examined seven different mitigating tools to relieve the pressure on airport capacities including the use of larger aircraft, high-speed trains, and schedule smoothing but unaccommodated demand still remains high (Eurocontrol, 2013).

\subsection{Policy Options and Stakeholders}

The Airport Policy Report published by the European Commission in December 2011 focussed on capacity and quality as the key issues to be addressed and proposed action in a number of areas, with particular emphasis on slot allocation, ground handling services and noise-related operating restrictions. Recognition of the trade-offs involved between liberalisation and environmental sustainability receives scant attention apart from the section dealing with aircraft noise where the objective is "...to find the optimal combination of the most cost-effective measures for balancing transport and mobility needs with noise protection levels" (European Commission, 2011: 7). The Report acknowledges the need for substantial investment in airport infrastructure and proposes several financing mechanisms for same. By 'democratising' air transport, particularly in relation to the socially inclusive nature of low-fare air transport, it becomes increasingly difficult to re-regulate demand in such a way that the economic and social benefits are compromised; as the UK Minister for Transport put it in 2002, "people who call for demand to be managed are saying that workers should be priced off planes" (Spellar, 2002).

Airlines operate to a commercial mandate based on profit generation and growth (Goetz \& Graham, 2004). The global airline industry carried almost 3 billion passengers and 46 million tonnes of freight last year; by 2050, these figures are projected to reach 16 billion and 400 million respectively (IATA, 2011). Deregulation and liberalisation policies around the world have facilitated this growth and airlines welcome the creation of competitive market places. What has dogged the industry however (with several notable individual exceptions) is poor profitability; the average net margin over the past 40 years is $0.1 \%$ and the margin achieved even in its best year (2010) fell far short of its 7\% / 8\% cost of capital. Against this backdrop, the appetite and wherewithal to adopt 'polluter-pays' principles in respect of environmental impact is limited. Technological advancements have allowed the amount of fuel required to fly one passenger one kilometre to halve since the 1970s but with such volumes of passengers flying today, the industry acknowledges that "the absolute level of CO2 emissions is still rising" (IATA, 2011: 10). In June of 2013, the International Air Transport Association (IATA), whose 240 airline members account for $84 \%$ of the world's air traffic, called on governments to agree a single, market-based measure to achieve the target of carbon neutral growth from 2020 and endorsed the role of ICAO in negotiating a global agreement for the aviation industry.

Located very much at the nexus of the liberalisation / sustainability conundrum are the airports. Traditionally viewed by governments and airlines alike as little more than infrastructure providers, they played little or no role in aviation policy. As increasingly commercialised and privatised entities, however, airport operators look to conduct their business in a way that maximises profit and stimulates future growth (Goetz \& Graham, 2004; Graham, 2011). This increased emphasis on competitiveness often starts with improving relative operational efficiency through a process of benchmarking in order to attract more business and generate more profits (Ahn and Min, 2014). As such, the representative body for airports in Europe, Airports Council International - Europe (comprising over 450 airports in 44 European countries which handle $90 \%$ of European commercial air traffic, over 1.5 billion passengers, 18 million tonnes of freight and 20 million aircraft movements each year) constantly pushes the case for allowing airports to expand and compete in an open market without the imposition of EU regulations relating to airport charges, slot allocation and ground handling. In effect, airports want 'open skies' to apply on the ground.

\section{Conclusions}

In essence, Europe faces two sets of inter-related 'irreconcilable differences', viz. how to garner the economic and social benefits derived from a competitive aviation marketplace within Europe without compromising its environmental sustainability obligations, and how to complete its application of ETS to aviation in the absence of a global policy or ensure that its conditions are met in the event that ICAO does conclude a global policy. 
The context in which these tensions arise has several virtually indisputable facts, viz. air transport demand in Europe is destined to experience strong, long-term growth; technological and operational enhancements can only provide limited mitigation in meeting this demand; the development of a feasible renewable fuel to replace oil is a long way off; and "aviation is moving in an unsustainable direction due to absolute increases in environmental consumption and emissions" (Upham et al., 2003: 16). Within Europe, it appears that "environmentally driven capacity constraints at airports will effectively determine air transport's development within the EU" (Graham and Guyer, 1999: 165). Internationally, all eyes now turn to the $39^{\text {th }}$ ICAO Assembly in 2016.

\section{References}

Ahn, Y. H., \& Min, H. (2014). Evaluating the multi-period operating efficiency of international airports using data envelopment analysis and the Malmquist productivity index. Journal of Air Transport Management, 39 12-22. http://dx.doi.org/10.1016/j.jairtraman.2014.03.005

Airports Council International (ACI). (2013). Air Transport Partners urge Action on Eurocontrol Airport Capacity Alert. Joint Press Release issued by ACI, European Regions Airline Association and the Association of European Airlines. Retrieved from https://www.aci-europe.org/press-releases.html

Aisling-Feighan, A. J., \& Button, K. J. (1999). An Assessment of the Capacity and Congestion Levels at European Airports. Journal of Air Transport Management, 5(3), 113-134. http://dx.doi.org/10.1016/S0969-6997(99)00006-X

Akerman, J. (2005). Sustainable Air Transport-On Track in 2050. Transportation Research Part D, 10 , 111-126. http://dx.doi.org/10.1016/j.trd.2004.11.001

Barrett, S. D. (1992). Barriers to contestability in the deregulated European aviation market. Transportation Research Part A: Policy and Practice, 26(2), 159-165. http://dx.doi.org/10.1016/0965-8564(92)90010-5

Bilotkach, V., Clougherty, J. A., Mueller, J., \& Zhang, A. (2011). Regulation, Privatisation, and Airport Charges: Panel Data Evidence from European Airports. Centre for Economic Policy Research, Discussion Paper No. 8618. Retrieved from http://www.cepr.org/pubs/dps/DP8618.asp

Black, W. R. (1996). Sustainable transport: a US perspective. Journal of Transport Geography, 4, 151-159. http://dx.doi.org/10.1016/0966-6923(96)00020-8

Budd, L., Francis, G., Humphreys, I., \& Ison, S. (2014). Grounded: characterising the market exit of low cost $\begin{array}{lllll}\text { airlines. Journal of Air Transport } & \text { Management, }\end{array}$ http://dx.doi.org/10.1016/j.jairtraman.2013.08.002

Eurocontrol. (2013). Challenges of Growth. Retrieved from http://www.eurocontrol.int/articles/challenges-growth

European Commission. (2011). Airport policy in the European Union-addressing capacity and quality to promote growth, connectivity and sustainable mobility. Retrieved from http://ec.europa.eu/transport/modes/air/airports/doc/2011-airport-package-communication_en.pdf

European Commission. (2011). Airport policy in the European Union-addressing capacity and quality to promote growth, connectivity and sustainable mobility. Retrieved from http://ec.europa.eu/transport/modes/air/airports/doc/2011-airport-package-communication_en.pdf

European Experience of Air Transport Liberalization. (2003). International Civil Aviation Organisation. Retrieved from http://www.icao.int/sustainability/CaseStudies/StatesReplies/EuropeLiberalization_En.pdf

Goetz, A. R., \& Graham, B. (2004). Air transport globalization, liberalization and sustainability: Post-2001 policy dynamics in the United States and Europe. Journal of Transport Geography, 12, 265-276. http://dx.doi.org/10.1016/j.jtrangeo.2004.08.007

Graham, A. (2011). The objectives and outcomes of airport privatisation. Research in Transportation Business \& Management, 1, 3-14.

Graham, B., \& Guyer, C. (1999). Environmental sustainability, airport capacity and European air transport liberalization: irreconcilable goals? Journal of Transport Geography, 7, 165-180. http://dx.doi.org/10.1016/S0966-6923(99)00005-8

Greene, D. L., \& Wegener, M. (1997). Sustainable transport. Journal of Transport Geography, 5, 177-190. http://dx.doi.org/10.1016/S0966-6923(97)00013-6 
IATA (International Air Transport Association). (2011). Vision 2050. Retrieved from http://www.iata.org/pressroom/facts_figures/Documents/vision-2050.pdf

IATA (International Air Transport Association). (2013). Resolution on the Implementation of the Aviation "CNG2020" Strategy. Retrieved from http://www.iata.org/pressroom/pr/Pages/index.aspx

ICAO (International Civil Aviation Organisation). Retrieved from http://www.icao.int/newsroom

Lee, D. S., Lim, L. L., \& Owen, B. (2013). Mitigating future aviation CO2 emissions-“timing is everything”. Retrieved from http://www.cate.mmu.ac.uk/docs/mitigating-future-aviation-co2-emissions.pdf

Madas, M. A., \& Zografos, K. G. (2008). Airport capacity vs. demand: Mismatch or mismanagement? Transportation Research Part A, 42, 203-226. http://dx.doi.org/10.1016/j.tra.2007.08.002

Murel, M., \& O'Connell, J. F. (2011). Potential for Abu Dhabi, Doha and Dubai Airports to reach their traffic objectives. Research in Transportation Business \& Management, 1, 36-46. http://dx.doi.org/10.1016/j.rtbm.2011.06.004

Reynolds-Feighan, A. J., \& Button, K. J. (1999). An Assessment of the Capacity and Congestion Levels at European Airports. Journal of Air Transport Management, 5(3), 113-134. http://dx.doi.org/10.1016/S0969-6997(99)00006-X

Spellar, J. (2002). Address to Freedom to Fly Conference 24 July. TUC Congress Centre, London.

Suau-Sanchez, P., Pallares-Barbera, M., \& Paul, V. (2011). Incorporating annoyance in airport environmental policy: noise, societal response and community participation. Journal of Transport Geography, 19, 275-284. http://dx.doi.org/10.1016/j.jtrangeo.2010.02.005

Upham, P., Thomas, C., Gillingwater, D., \& Raper, D. (2003). Environmental capacity and airport operations: current issues and future prospects. Journal of Air Transport Management, 9, 145-151. http://dx.doi.org/10.1016/S0969-6997(02)00078-9

\section{Copyrights}

Copyright for this article is retained by the author(s), with first publication rights granted to the journal.

This is an open-access article distributed under the terms and conditions of the Creative Commons Attribution license (http://creativecommons.org/licenses/by/3.0/). 